\title{
Supramolecular Photochemistry and Solar Cells
}

\author{
NEYDE YUKIE MURAKAMI IHA \\ Laboratório de Fotoquímica Inorgânica e Conversão de Energia, \\ Instituto de Química, Universidade de São Paulo, \\ Cx. Postal 26.077 - 05513-970, São Paulo, SP, Brazil \\ Manuscript received on September 8, 1999; accepted for publication on September 15, 1999; \\ presented by José M. RIVERos
}

\begin{abstract}
Supramolecular photochemistry as well as solar cells are fascinating topics of current interest in Inorganic Photochemistry and very active research fields which have attracted wide attention in last two decades. A brief outline of the investigations in these fields carried out in our Laboratory of Inorganic Photochemistry and Energy Conversion is given here with no attempt of an exhaustive coverage of the literature. The emphasis is placed on recent work and information on the above mentioned subjects. Three types of supramolecular systems have been the focus of this work: (i) cage-type coordination compounds; (ii) second-sphere coordination compounds, exemplified by ion-pair photochemistry of cobalt complexes and (iii) covalently-linked systems. In the latter, modulation of the photoluminescence and photochemistry of some rhenium complexes are discussed. Solar energy conversion and development of thin-layer photoelectrochemical solar cells based on sensitization of nanocrystalline semiconductor films by some ruthenium polypyridyl complexes are presented as an important application that resulted from specifically engineered artificial assemblies.
\end{abstract}

Key words: inorganic photochemistry, supramolecular photochemistry, solar cells, photoelectrochemical devices.

\section{INTRODUCTION}

The photophysical and photochemical behavior of several $d^{6}$ transition metals coordinated to $N$-heterocyclic ligands have been intensively investigated (Baba et al. 1998, Omberg et al. 1999, and references therein). A variety of applications based on fundamental investigation of photophysical and photochemical properties have emerged, such as luminescence-based sensors and displays, photoreactive polymers and dye-sensitization of semiconductors (Schanze \& Schmehl 1997).

The development of more complex systems, especially within the framework of supramolecular chemistry, gives rise to the possibility of design-

E-mail: neydeiha@quim.iq.usp.br ing organized systems as components of molecularlevel photochemical devices (Lehn 1995, 1988). Supramolecular systems are constituted of a number of discrete molecular components with definite individual properties, held together by chemical interactions. This organization is particularly interesting for the development of systems capable of performing useful functions, such as use of light for energy or information purposes (Balzani et al. 1998). These chemical systems have led to applications of inorganic photochemistry in areas such as biological chemistry, luminescence sensors, and advanced materials (Schanze \& Schmehl 1997).

Molecular devices are assemblies of molecular components designed to achieve specific functions, such as photoinduced electron and energy transfer in 
solar energy conversion, electron collection, remote photosensitization, antenna effect, photoswitching of electric signals, light-energy up conversion, photoinduced structural changes in switch on/off applications (photoisomerizable systems), molecular wires and sensors, in analytical chemistry, and in the development of new materials and nanoscale electronic devices (Balzani 1987, Meyer 1989, Balzani \& Scandola 1991, Lehn 1995, Meyer 1997, Schanze \& Schmehl 1997, Kalyanasundaram \& Grätzel 1998). In this aspect, caged metal ions, their ionpairs and some covalently-linked systems studied by our group will be discussed here. Also, regenerative photoelectrochemical cells and some ruthenium complexes used as sensitizer for charge injection into nanocrystalline semiconductors will be presented to illustrate an application that has evolved from a fundamental investigation of inorganic photochemistry by use of a specifically designed assembly to conceive artificial molecular devices.

\section{SUPRAMOLECULAR PHOTOCHEMISTRY}

A particular type of perturbation can be introduced when a metal ion is encapsulated in a single, polydentate cage-type ligand. For instance, cobalt(III) sepulcrate, $[\mathrm{Co}(\mathrm{sep})]^{3+}$ where sep $=1,3,6,8,10,13$, 16,19-octaazabicyclo[6.6.6] eicosane, is considered a caged version of hexaamine cobalt(III), $\left[\mathrm{Co}\left(\mathrm{NH}_{3}\right)_{6}\right]^{3+}$, and presents a similar absorption spectrum, while its photochemical reactivity is quite different $\left(\Phi<10^{-6}\right)$ in comparison to the noncaged $\left[\mathrm{Co}\left(\mathrm{NH}_{3}\right)_{6}\right]^{3+}$ complex $(\Phi=0.16)$ (Balzani et al. 1986). Because of its characteristics, $[\mathrm{Co}(\mathrm{sep})]^{3+}$ can be used as an electron transfer photosensitizer in ion-pair systems. When the photoreaction is carried out in the presence of colloidal platinum, the complex plays the role of a photosensitizer for the evolution of hydrogen from aqueous solutions with oxalate ions as sacrificial agent (Pina et al. 1985, Garcia et al. 1999 and references therein).

The complex $f a c-\left[\left(\mathrm{Co}(\mathrm{pic})_{3}\right]^{3+}\right.$, where pic $=$ 2-aminomethylpyridine, may be considered the simplest non-caged analogue of $[\mathrm{Co}(\mathrm{sep})]^{3+}$, exhibiting similar redox and photochemical properties. In our work, we obtained the true quantum yield of the photoprocess by investigating both the fac$\left[\left(\mathrm{Co}(\text { pic })_{3}\right]^{3+}\right.$ and $[\mathrm{Co}(\text { sep })]^{3+}$ ion-pair systems with $\mathrm{C}_{2} \mathrm{O}_{4}^{2-}$, determining the ion-pair association constant under the same conditions as the photochemical studies (Azzellini et al. 1996, Garcia et al. 1999). The study of the static as well as dynamic process has also been performed for the

$$
[\mathrm{Co}(\mathrm{sep})]^{3+} / \mathrm{C}_{2} \mathrm{O}_{4}^{2-}
$$

system. One of the important features of these processes is based on a photoredox water splitting cycle, where the complex can play the role of an electron mediator relay. A disadvantage is the use of sacrificial scavengers, for instance oxalate or EDTA, to avoid back reaction (Balzani 1987, Garcia et al. 1999).

A metal complex sensitized intraligand photochemistry and the use of the photoisomerizable properties of the trans-1,2-bis(4-pyridyl)ethylene, $t$-bpe, were exploited to investigate photoresponsive structural change and modulation of the photoluminescence of $f a c-\left[\operatorname{Re}(\mathrm{CO})_{3}(\text { phen })(t \text {-bpe })\right]^{+}$, where phen $=1,10$-phenanthroline (Itokazu \& Murakami Iha 1999). Upon coordination, the quantum yields for the isomerization were higher than compared to the free ligand, even at $365-\mathrm{nm}$ irradiation, which is ineffective for photolysis of the ligand itself. Also an increasing luminescence centered at $570 \mathrm{~nm}$ is observed at room temperature as the $c i s$-isomer is formed and makes this photoassisted isomerization of the ligand an interesting feature in the design of photochemical molecular devices with an attractive characteristic for photoswitches.

On the other hand, when the complex forms a binuclear species with the $\left[\mathrm{Fe}(\mathrm{CN})_{5}\right]^{3-}$ moiety, a new $\mathrm{Fe}^{\mathrm{II}} \rightarrow t$-bpe MLCT low energy transition $\left(\lambda_{\max }=600 \mathrm{~nm}\right)$ appears. No isomerization process can be detected in photochemical experiments performed with methanolic solutions of

$$
\left[\operatorname{Re}(\mathrm{CO})_{3}(\text { phen })(t \text {-bpe }) \mathrm{Fe}(\mathrm{CN})_{5}\right]^{2-}
$$

due to an effective deactivation pathway to MLCT states quenching the photoisomerization process (Itokazu et al. 1997). Such systems, where the excitation causes the trans-cis isomerization, are also 
employed to control coordination ability by light (Balzani et al. 1998).

Covalently-linked systems involving cyanoferrate(II) complexes and $\left[\mathrm{Cr}(\mathrm{bpy})_{2}(\mathrm{BL})\right]^{3+}$, where bpy $=2,2$ '-bipyridine, $\mathrm{BL}=$ the bidentate bridging ligand 2,2'-bipyrimidine (bpm) or 2,3-bis(2'pyridyl)pyrazine (dpp), were also investigated. The iron chromophore presents intense bands in the visible region and unreactive MLCT states toward photosubstitution reactions, appropriate for antenna fragments, while the monomeric $\left[\mathrm{Cr}(\mathrm{bpy})_{2}(\mathrm{dpp})\right]^{3+}$ and $\left[\mathrm{Cr}(\mathrm{bpy})_{2}(\mathrm{bpm})\right]^{3+}$ species present at $77 \mathrm{~K}$ a sharp ${ }^{2} E \rightarrow{ }^{4} A_{2}$ emission around $715 \mathrm{~nm}$ (Lima et al. 1993), which characterizes good luminophores. In general, light absorption by the chromophore is followed by emission from the luminophore, the so called photonic molecular wire (Petersen et al. 1991).

The lack of emission for both $\left[(\mathrm{CN})_{4} \mathrm{Fe}(\mathrm{bpm})\right.$ $\left.\mathrm{Cr}(\mathrm{bpy})_{2}\right]^{+}$and $\left[(\mathrm{CN})_{4} \mathrm{Fe}(\mathrm{dpp}) \mathrm{Cr}(\mathrm{bpy})_{2}\right]^{+}$bimetallic species upon excitation of the intense MLCT band in the visible region indicated intermediate or possibly even strongly coupled metal centers (Lima et al. 1993).

These investigations show that supramolecular photochemistry involving covalently-linked systems can be exploited as a base for the building blocks to perform a specific function. In polynuclear complexes, the metal-based components are linked together by bridging ligands, which determine the structure of the system and control the electronic communication between the metal-based components. The preparation and characterization of these compounds having desired photophysical and photochemical characteristics is one of the most important areas of research in this field.

\section{SOLAR CELLS}

Chemically-based systems such as photogalvanic and photoelectrochemical cells have been developed as an alternative to solid-state silicon-based cells for the conversion of solar energy into electricity (Connolly 1981, Grätzel 1983 and references therein).

The use of coordination compounds as light absorbers, for instance $\left[\mathrm{Ru}(\mathrm{bpy})_{3}\right]^{2+}$ was one of the first approaches to convert low-energy starting materials into high-energy products, such as $\mathrm{H}_{2} \mathrm{O}$ into $\mathrm{H}_{2}$ and $\mathrm{O}_{2}$, in homogeneous cells. Although ingenious, the drawback was the low efficiencies (light-to- electrical conversion efficiency $<0.5 \%$ ) due to the fast recombination of the photoproducts in the solution (Connolly 1981). The answer seemed to be the use of photoelectrochemical cells, in which a semiconductor electrode was the light absorber with the band bending separating the reduction and oxidation sites. However, these cells displayed low efficiency conversion of visible light into redox energy, and were limited to the band-gap of the semiconductors employed (Connolly 1981, Wrighton 1983). The use of photostable wide band-gap semiconductors would require high-energy light to create electronhole pairs and dye sensitization was of limited utility because of sub-monolayer coverage and low absorptivities, although it presented advantages over direct band to band excitation as in conventional solar cells due to the reduction of electron-hole recombination.

The development of mesoporous membrane type film with large surface areas prepared from nanosized colloidal semiconductor dispersion caused a remarkable growth in the field (Brown Jr. et al. 1999). Dye sensitization of nanostructured wide band-gap semiconductors has led to an extension of their photoresponse into the visible region and to efficient conversion of solar energy into electricity in photoelectrochemical devices (O'Reagan \& Grätzel 1991). Similarly to chlorophyll molecules, adsorbed dyes act as light absorbing antenna to mimic the photosynthetic process by promoting photoinduced charge separation in an organized molecular structure on the nanometric scale.

In this approach, attached dyes, rather than the semiconductor itself, are the absorbing species and upon excitation inject electrons into the semiconductor conduction band which are then collected at a conducting surface, keeping the electron-hole pair separated and generating photocurrent. As a result of this advance, the development of low-cost efficient photochemical solar cells became possible (O’Reagan \& Grätzel 1991, Ball 1997).

As one of these promising devices, we have 

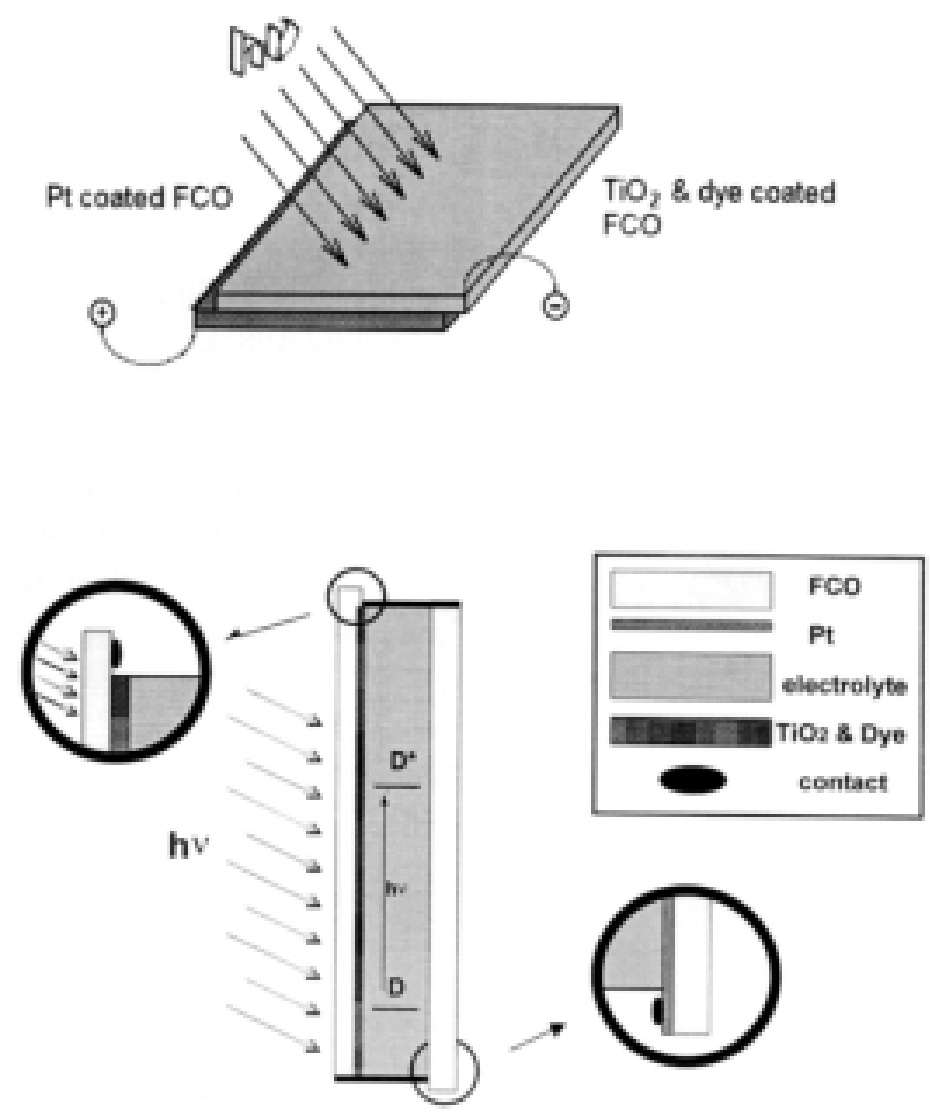

Fig. 1 - Thin-layer transparent sandwich-type solar cell and its components.

been developing thin-layer, transparent sandwichtype solar cells (Murakami Iha et al. 1998, Garcia et al. 1998a,b 1999). The cell, as in Figure 1, consists of a fluorine doped $\mathrm{SnO}_{2}$ conducting glass, FCO, with the $n-\mathrm{TiO}_{2}$ film sensitized by a complex, as a photoanode, and a transparent Pt film on a conducting glass, as a counter electrode, arranged in a sandwich configuration with $\mathrm{LiI} / \mathrm{I}_{2}$ solution, as the redox relay, filling the inter-electrode space.

A series of sensitizers, $c i s-\left[\left(\mathrm{dcbH}_{2}\right)_{2} \mathrm{RuLL}^{\prime}\right]$ derivatives, where $\mathrm{L}$ and $\mathrm{L}^{\prime}=\mathrm{H}_{2} \mathrm{O}, \mathrm{X}^{-}$, 4-phenylpyridine, isoquinoline, 4-cyanopyridine etc., and $\mathrm{dcbH}_{2}=4,4^{\prime}-\left(\mathrm{CO}_{2} \mathrm{H}\right)_{2}-2,2^{\prime}$ '-bipyridine, were specially engineered and synthesized to promote electron injection after light excitation (Garcia et al. 1998a,b 1999). These compounds have good sensitizing properties due to broad absorption spectra with intense MLCT bands overlapping the solar spectrum, combined with suitable redox properties. The carboxylic groups provide for strong adsorption of the dye to the $\mathrm{TiO}_{2}$ surface and the necessary electronic coupling between the charge-transfer excited state of the sensitizer and the wavefunction of the semiconductor conduction band, which results in the very fast electron transfer.

The oxidized dye $\left(\mathrm{D}^{+}\right)$is quickly regenerated by the redox mediator couple $I_{2} / I_{3}^{-}$present in the filling electrolyte which, in turn, is regenerated at the counter-electrode, concluding the redox cycle. The reduction of $I_{2}$ is catalyzed by small amounts of Pt deposited on the counter electrode. The system operates as a regenerative electrochemical cell, in which visible light is efficiently converted into electricity without any permanent chemical change.

Electron injection into the conduction band of semiconductors from an excited sensitizer allows 
population of the band with light of energy lower than the semiconductor band-gap, providing a good match with the solar spectrum in ideal cases for practical applications. The theoretical maximum output voltage that can be achieved corresponds to the difference between the redox potential of the mediator couple and the Fermi level (conduction band) of the semiconductor under illumination (Kalyanasundaram \& Grätzel 1993, 1998). Several parameters such as spectral and redox properties of the dye, efficiency of charge injection and structural properties of the semiconductor electrode to collect and direct electrons through the external circuit determine the photocurrent values.

Under a special program promoted by our University for development of strategic fields of research, so called CIUPE, development of solar cells and investigations of thin films have been carried out in a cooperative effort between our laboratory and other research groups, including the participation of a company. Thin-layer $\mathrm{TiO}_{2}$ film deposition techniques, such as spin-coating and painting, have been compared and provided a way to control physical properties, such as film thickness and homogeneity (Garcia \& Murakami Iha 1999). Also, the IndustryUniversity collaboration has been a unique experience, providing students at both the undergraduate and graduate levels with the multi-disciplinary environment to become qualified professionals for many areas of modern science and technology in applied research (Garcia et al. 1997). A layer of $\mathrm{TiO}_{2}$ film deposited on a FTO is porous with a high surface area and after heating to reduce the film resistivity acts as a sponge to take up the sensitizer.

The effectiveness for the sensitization of nanocrystalline $\mathrm{TiO}_{2}$ films was determined employing several dyes prepared in our Laboratory of Inorganic Photochemistry and Solar Energy Conversion at the IQ-USP, demonstrating the feasibility of operating photoelectrochemical solar cells. Timeresolved transient absorption experiments are in progress to monitor the photochemical changes and kinetics.

These novel sensitizers provided an enhanced spectral response of $\mathrm{TiO}_{2}$ to visible light and effi- cient charge separation in the regenerative thin-layer sandwich-type solar cells described here. Quantitative evaluation of the thin-layer, transparent sandwich-type solar cell performance can be given by measurements of the incident photon-to-current conversion efficiency (IPCE) for monochromatic radiation and can be considered as the effective quantum yield for the device. The photocurrent action spectra obtained for cells with dye coated $n$-type $\mathrm{TiO}_{2}$ electrodes resulted in respectable IPCE values up to $50 \%$ until $550 \mathrm{~nm}$ (Garcia et al. 1999). Therefore, these complexes present good light harvesting properties and act as efficient charge-transfer sensitizers for nanocrystalline $\mathrm{TiO}_{2}$ in solar cells, converting effectively visible light into electricity. The values confirm that the dyes adsorb efficiently to nanoporous $\mathrm{TiO}_{2}$ with very high surface roughness, and are comparable or higher to those obtained by other ruthenium(II) polypyridyl-based sensitizers (Hagfeldt \& Grätzel 1995, Meyer 1997).

\section{ACKNOWLEDGEMENTS}

Support of the work reported here by the CNPq and the FAPESP is gratefully acknowledged. I would like to thank Profs. V. K. L. Osorio, D. L. A. Farias, F. R. Ornellas, C. A. Bignozzi and T. J. Meyer for collaboration and discussion, and to my cooperative and lively group, Dr. J. F. Lima and students - André S. Polo, Adriana N. Geraldes, Christian G. Garcia, Denis R. M. de Godoi, Maria de Fátima P. de Oliveira, Melina K. Itokazu and Yasmin R. A. Gomes, who have carried out experiments of the research work presented here.

\section{REFERENCES}

Azzellini MAA, De Oliveira MFP, MuraKami Iha NY \& OsORIO VKL 1996. The ion-pair association constant of oxalate with fac-tris(2-aminomethylpyridine)cobalt(III), Polyhedron, 15: 4579-4584.

Baba AI, Shaw JR, Simon JA, Thummel RP \& SCHMEHL RH 1998. The photophysical behavior of $d^{6}$ complexes having nearly isoenergetic MLCT and ligand localized excited states, Coord Chem Rev 171: 43-59. 
Ball P 1997. Made to Measure - New Materials for the $21^{\text {st }}$ Century. Princeton University Press, New Jersey, 278-281.

Balzani V (Ed) 1987. Supramolecular Photochemistry, Nato ASI Series, 214, D. Reidel Pub. Co., Dordrecht, 469pp.

Balzani V \& Scandola F 1991. Supramolecular Photochemistry, Ellis Horwood Ltd., West Sussex, 427pp.

Balzani V, Credi A \& Venturi M 1998. Photochemistry and photophysics of coordination compounds: an extended view. Coord Chem Rev 171: 3-16.

Balzani V, Sabbatini N \& Scandola F 1986. "Second Sphere" photochemistry and photophysics of coordination compounds. Chem Rev 86: 319-337.

Brown Jr GE, Henrich VE, Casey WH, Clark DL, Eggleston C, Felmy A, Goodman DW, Grätzel M, Maciel G, McCarthy Mi, Nealson KH, SverJensky DA, Toney MF \& ZaChara JM 1999. Metal oxide surfaces and their interactions with aqueous solutions and microbial organisms. Chem Rev 99: $77-174$.

Connolly JS (Ed) 1981. "Photochemical Conversion and Storage of Solar Energy", Academic Press, New York, 444pp.

Garcia CG. \& Murakami Iha NY 1999. Células solares fotoeletroquímicas baseadas em filmes semicondutores de $\mathrm{TiO}_{2}$ nanocristalino sensibilizados por complexos inorgânicos de rutênio. Anais Simp Brasil Eletroquim Eletroanal 11: 699-702.

Garcia CG, Lima JF \& Murakami Iha NY 1999. Energy conversion: from the ligand field photochemistry to solar cells, Coord Chem Rev, in press, 30pp.

Garcia CG, Murakami Iha NY, Argazzi R \& BigNOZZI CA 1998a. Sensitization of n-type $\mathrm{TiO}_{2}$ electrodes by a novel isoquinoline ruthenium(II) polypyridyl complex. J Braz Chem Soc 9: 13-15.

Garcia CG, Murakami Iha NY, Argazzi R \& BigNOZZI CA 1998b. 4-phenylpyridine as ancillary ligand in ruthenium(II) polypyridyl complexes for sensitization of n-type $\mathrm{TiO}_{2}$ electrodes. J Photochem, Photobiol: Chem 115: 239-242.

Garcia CG, Polo AS, Murakami Iha NY \& Bignozzi
CA 1997. New solar cells: An example of a University-industry partnership. $2^{\text {nd }}$. International Conference on Industry-Education Co-operation, 44, São Bernardo do Campo, Brasil.

Grätzel M (Ed) 1983. Energy Resources through Photochemistry and Catalysis, Academic Press, New York, 572pp.

Hagfeldt A \& Grätzel M 1995. Light-induced reactions in nanocrystalline systems. Chem Rev 95: 49-68.

ITOKAZu MK \& Murakami Iha N Y 1999. Photoresponsive structural change and modulation of the photoluminescence of $f a c$ - $\left[\operatorname{Re}(\mathrm{CO})_{3}\right.$ (phen $)(t$-bpe $\left.)\right]$ PF $_{6}$. Proc. $13^{\text {th }}$ Int Symp Photochem Photophys Coord Chem, Isle of Lipari, P53.

Itokazu MK, Polo AS, Murakami Iha NY \& BigNOZZI CA 1997. Photochemical properties of trans1,2bis(4-pyridyl)ethylene coordinated to tricarbonyl(phenatroline)rhenium(I), Proc. $12^{\text {th }}$ Int. Symp Photochem Photophys Coord Chem, Vermont, P59.

Kalyanasundaram K \& Grätzel M (Eds) 1993. Photosensitization and Photocatalysis Using Inorganic and Organometallic Compounds, Kluwer Academic Pub., Dordrecht, 465pp.

Kalyanasundaram K \& Grätzel M 1998. Application of funcionalized transition metal complexes in photonic and optoelectronic devices. Coord Chem Rev 77: 347-414.

LEHN J-M 1988. Supramolecular chemistry - Scope and perspectives molecules, supermolecules, and molecular devices (Nobel Lecture), Angew Chem Int Ed Engl 27: 89-112.

LEHN J-M 1995. Supramolecular Chemistry, VCH, Weinheim, Germany, 271pp.

Lima JF, Murakami Iha NY \& Petersen J 1993. Síntese e caracterização dos complexos bimetálicos $\left[(\mathrm{CN})_{4} \mathrm{Fe}(\mathrm{BL}) \mathrm{Cr}(\mathrm{bpy})_{2}\right]^{+}, \mathrm{BL}=$ bpm e dpp, e seus análogos monoméricos. Reunião Anual da Sociedade Brasileira de Química, 16: QI-97, Caxambu.

Meyer GJ (Ed) 1997. Molecular Level Artificial Photosynthetic Materials. Prog Inorg Chem 44: 408pp.

Meyer TJ 1989. Chemical approaches to artificial pho- 
tosynthesis. Acc Chem Res 22: 163-170.

Murakami Iha NY, NaKano AK \& Garcia CG 1998. Fotoquímica inorgânica na conversão de energia solar. An Assoc Bras Quím 47: 46-56.

Omberg KM, Smith GD, Kavaliunas DA, Chen PY, Treadway JA, Schoonover JR, Palmer RA \& MEYER TJ 1999. Excited-state structure in polypryridyl complexes containing unsymmetrical ligands. Inorg Chem 39: 951-956.

O’Reagan B \& Grätzel M 1991. A low-cost, highefficiency solar cell based on dye-sensitized colloidal $\mathrm{TiO}_{2}$ films. Nature 353: 737-740.

Petersen JD, Morgan LW, Hsu I, Billadeau MA \& RoNCO SE 1991. Excited-state energy- and electrontransfer reaction in multimetal systems. Coord Chem Rev 111: 319-324.
Pina F, Mulazzani QG, Venturi M, Ciano M \& BALZANI V 1985. Photochemistry of Co(sep $)^{3+}$. oxalate ion-pairs - a novel system for dihydrogen evolution from aqueous-solutions. Inorg Chem 24: 848-851.

Schanze KS \& Schmehl RH (Eds) 1997. Application of inorganic photochemistry in the chemical and biological sciences. J Chem Educ 74: 633-702.

Wrighton MS 1983. Photoelectrochemistry: inorganic photochemistry at semiconductor electrodes. JChem Educ 60: 877-881. 